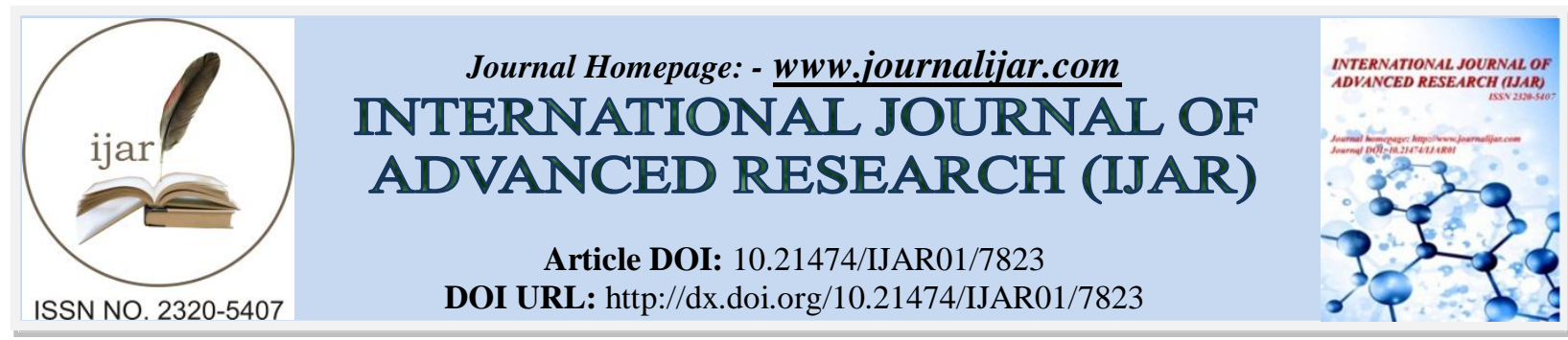

RESEARCH ARTICLE

\title{
ANTIESTROGENIC AND ANTIANDROGENIC ACTIVITIES OF A HYDRO-ALCOHOLIC LEAF EXTRACT OF PENTADESMA BUTYRACEA (CLUSIACEAE).
}

Tindano Basile ${ }^{1}$, Bayala Balé ${ }^{1}$, Doukouré Maya ${ }^{1}$,Wober Jannette ${ }^{2}$, Keiler M. Annekathrin ${ }^{2,3}$, Zierau Oliver $^{2}$, , Günter Vollmer', Belemtougri G. Raymond ${ }^{1}$.

1. Laboratoire de Physiologie animale, Université Ouaga I Pr Joseph Ki-ZERBO.

2. Department of Molecular Cell Physiology and Endocrinology, Institute for Zoology, Technische Universität Dresden, 0106 Dresden, Germany.

3. Institute of Doping Analysis and Sports Biochemistry Dresden, Kreischa, Germany

\section{Manuscript Info}

(1..........................

Manuscript History

Received: 6 August 2018

Final Accepted: 8 September 2018

Published: October 2018

Keywords:

Pentadesma butyracea, antiestrogenic, antiandrogenic, phytohormones.

\section{Abstract}

Menopausal symptoms and hormone-related diseases such as breast and prostate cancers are serious problems of public health. The management of these diseases is extremely expensive for populations in developing countries with low outcomes. As alternative, medicinal plants are the most used for healthcare in these countries. Therefore, several preclinical studies are performed to screen phytoestrogens and phytoandrogens which can exhibit health benefits for management of these symptoms and hormone-related diseases. Pentadesma butyracea is a West African rainforest species used traditionally for management of reproductive disorders and treatment of breast pain. Thus, the aim of this study was to assess hormone-like activities of a hydro-alcoholic leaf extract of $P$. butyracea by in vitro and in vivo assays. Yeast estrogen/androgen screen were performed to evaluate (anti)estrogenic and (anti)androgenic activities of the extract. For the in vivo assay, Hershberger bioassay was performed in immature male Wistar rats. The weight of accessory glands was used for the evaluation of (anti)androgenic activities. Immature uterotrophic bioassay was used as in vivo assay for detection of possible (anti)estrogenic activities based on uterine, ovarian and adrenal weight. In the yeast estrogen/androgen screen, the extract exhibited antiestrogenic and antiandrogenic activities. In vivo assays confirmed that the extract exhibited antiandrogenic $(p<0.05)$ activity but did not have antiestrogenic activity. Overall, the extract did not exhibit estrogenic and androgenic properties, but showed antiestrogenic activity in vitro and antiandrogenic activities both in vitro and in vivo. These findings showed the extract can antagonized estrogenic activity and could act Selective Androgen Regulator Modulators. Therefore, it can have a great potential of application for regulation of sex hormone target tissues including management of hormone-related diseases. Nevertheless, subsequent studies are necessary to assess its safety in terms of breast and prostate cancer.

Copy Right, IJAR, 2018,. All rights reserved. 


\section{Introduction:-}

Menopausal symptoms as well as hormone-related diseases such breast and prostate cancer have become a challenge for the public health system. Recently, the incidence of breast and prostate cancer is increasing markedly worldwide and needs to be addressed (OMS, 2013, Siegel et al., 2017). Indeed, in the United States, prostate cancer is the most common cancer in men with $19 \%$ of all new cancer cases in the year 2017 (Siegel et al., 2017). Similarly, breast cancer is the most common cancer in women with $30 \%$ of new cases in 2017. Although recent statistic data is not yet available for Africa and especially for West Africa, breast and prostate cancer occupy here, the first place among women and men too. Despite the increase of cases of these hormone-related diseases, the treatment remains either very expensive or unavailable (Delma, 2011; Kaboré et al., 2014). Consequently, there is real need in developing countries, to find an affordable alternative therapy e.g. through plant-derived products. Indeed, medicinal plants remain the first issue for primary healthcare in developing countries. Since the discovery of phytoestrogens and phytoandrogens, plant metabolites which interfere with male and female reproductive function, there is a large and controversial debate concerning their possible benefit or risk for healthcare. Whereas the reproduction of some animals is disrupted by plant derived substances, several reports revealed the beneficial effects of secondary plant metabolites for management of menopausal symptoms and hormone-related diseases (Levitsky and Dembitsky, 2015; Rietjens et al., 2017). Thus, the biological screening of phytohormones is a very dynamic field for scientific activities.

Pentadesma butyracea is a rainforest species distributed from Sierra Leone to Cameroon. Its different organs are used as spices and for medicinal purposes. Traditionally, leaves, bark and roots of P. butyracea is used to treat reproductive disorders and breast pain (Sinsin and Sinadouwirou, 2003; Avocevou-Ayisso et al., 2011; Ouedraogo et al., 2013). Previous studies showed that leaves essential oil, and bark of P. butaracea has anti-plasmodial, antiproliferative, anticancer, antimicrobial and antioxidant activities (Noudogbessi et al., 2013; Tala et al., 2013; Tamokou et al., 2013). Recently, it has been reported that $P$. butyracea seed extract presents estrogenic, antiandrogenic and antioxidant activities (Hilou et al., 2017; Tindano et al., 2017). However, there is lack of scientific data about the effect of $P$. butyracea leaf extract on the reproductive system. Hypothetically, the leaf of $P$. butyracea contain hormonally active secondary plant metabolites which can be used as alternative for hormone replacement therapy. The aim of this study was to assess phytohormonal activities of a hydro-alcoholic leaf extract of $P$. butyracea.

\section{Materiels And Methods:- \\ Sample collection and extraction}

Fresh leaf of $P$. butyracea were collected in Banfora (Peni) (Western part of Burkina Faso) during October 2015. Samples were authenticated in the Laboratory of Botany of the University Ouaga I Pr Joseph KI-ZERBO where a voucher specimen was deposited with a reference number (ID number: 16973, sample number: 6847). Then, fresh leaf was washed with tap water and dried in laboratory conditions (without dust and sunlight) and under artificial ventilation at room temperature. Dried leaf was powdered and used for extraction.

For extraction, $1000 \mathrm{~mL}$ of water-alcohol 80/20 (v/v) was added to $100 \mathrm{~g}$ of powdered leaf in Erlenmeyer of 2000 $\mathrm{mL}$ of capacity. The mixture was homogenized with a glass stick and kept at room temperature for 24 hours. The mixture was periodically shaken. After 24 hours, the mixture was filtered and distributed in crystallizing-pan (capacity: $500 \mathrm{~mL}$ ) and was evaporated under a reduce pressure at $45^{\circ} \mathrm{C}$ in rotavapor during 24 hours. The extract was stored at $4^{\circ} \mathrm{C}$ till used. The yield of hydro-alcoholic leaf extract of $P$. butyracea was $9.5 \%$

\section{Chemicals}

Testosterone-propionate (97 \%), dihydrotestosterone (DHT), 17 -estradiol (E2) and 17ß-estradiol 3-benzoate (98 \%) were purchased from sigma Aldrich chemical Co (St. Louis, MO, USA).

\section{Yeast estrogen screen (YES)/Yeast Androgens Screen (YAS)}

Yeast estrogen screening assay was kindly provided by Prof. Sumpter (Brunel university), and the assay was performed as described by Routledge and Sumpter (1996).

Yeast androgen screening principle is similar to yeast estrogen assay, was obtained from PGKhAR strain and was performed as described by Sohoni and Sumpter (1998).

In brief, stock solutions of the test substances (17 $\beta$-estradiol and dihydrotestosterone) $\left(10^{-9}\right.$ to $\left.10^{-4} \mathrm{M}\right)$ and hydroalcoholic extract of $P$. butyracea were prepared and serially diluted in DMSO. Aliquots of $2 \mu \mathrm{L}$ of each 
concentration were transferred to 96-well optically flat bottom microtiter plate. Test medium containing yeast and CPRG was added to achieve final volume of $200 \mu \mathrm{L}$ and the concentration of DMSO was lesser than $1 \%$. The final concentration of the chemicals (17 $\beta$-estradiol and dihydrotestosterone) and the extract in the wells were range from $10^{-11}$ to $5.10^{-6} \mathrm{M}$ and 0.2 to $10 \mathrm{mg} / \mathrm{mL}$, respectively. Each treatment was in quadruplicate and, $17 \beta$-estradiol and dihydrotestosterone were used as positive controls in YES and YAS, respectively. The DMSO $1 \%$ was used as blank control. The plates were sealed with wax paper and incubated in thermoshaker at $30^{\circ} \mathrm{C}$. The hAR plates were removed after 24 hours and incubated at $28{ }^{\circ} \mathrm{C}$ to optimise the reaction without risking a significant increase in background expression of $\beta$-galactosidase whereas hER plates were removed after 72 hours. The colour change was read spectrophotometrically (Megallan 6 plate reader, Tecan) at regular intervals at absorbance of $560 \mathrm{~nm}$ and 690 $\mathrm{nm}$. Absorbance at $690 \mathrm{~nm}$ allowed correction for turbidity (a measure of growth rate of the yeast and therefore compound toxicity effect). Following incubation, a deep red colour denotes positive activity and negative control wells appear light orange in colour (Routledge and Sumpter, 1996; Sohoni and Sumpter, 1998).

Antiestrogenic and antiandrogenic activities were assessed as described previously (Routledge and Sumpter, 1997; Sohoni and Sumpter, 1998). Aliquots of $2 \mu \mathrm{L}$ of each concentration was transferred in the wells (four wells). The natural ligands (17 $\beta$-estradiol and dihydrotestosterone) were added to the medium at appropriate concentration $\left(5 \times 10^{-7} \mathrm{M}\right)$ which produces sub-maximal response. The ability of the extract to inhibit the activity induced by natural ligand was assessed by measurement of the reduction of colour changed.

\section{Animal model and ethic consideration}

Immature female and male Wistar rats of 21 to 24 days-old from the animal unit of University Ouaga I Pr. Joseph KI-ZERBO were used. These animals were bred under controlled environmental conditions including temperature $\left(22 \pm 3{ }^{\circ} \mathrm{C}\right)$, relative humidity $(50 \pm 10 \%)$, photoperiod (light-dark cycle 12 hours /12 hours). Water and rodent phytoestrogen free pellet diet were available ad libitum. The experimental procedure as well as all animal handling respected the ethical standards compiled in the 1964 Declaration of Helsinki and the experimental protocols were chosen and conducted to adhere as closely as possible to the $3 \mathrm{R}$ principles of animal welfare. All the tests were approved by the Laboratory of Animal Physiology of University Ouaga I Pr. Joseph KI-ZERBO and met the international standard of animals' study (Zimmermann, 1983).

\section{Hershberger bioassay}

Hershberger bioassay was used to investigate possible androgenic and antiandrogenic activities as described by Andrade et al. (2002) and OECD (2009). Immature male Wistar rats aged 22-24 days weighing 38,59 $\pm 3,44 \mathrm{~g}$ were randomly divided into 6 groups of 6 rats each and treated daily for 10 consecutive days. Groups 1 and 2 were given 100 and $200 \mathrm{mg} / \mathrm{kg}$ of hydro-alcoholic leaf extract of $P$. butyracea for assessment of androgenic activity. Group 3 was treated with sterilized water and was considered as the blank whereas group 4 was treated with testosteronepropionate (TP, 700 $\mu \mathrm{g} / \mathrm{kg} \mathrm{bw}$ ) and was considered as reference control. For assessment of antiandrogenic activity, group 5 was co-treated with $100 \mathrm{mg} / \mathrm{kg}$ of the extract and TP (700 $\mu \mathrm{g} / \mathrm{kg} \mathrm{bw})$ whereas group 6 was co-treated with $200 \mathrm{mg} / \mathrm{kg}$ of the extract and TP $(700 \mu \mathrm{g} / \mathrm{kg}$ bw). Reference control (TP) was administered intraperitoneal, whereas sterilized water and extract were given orally by gavage. Twenty-Four (24) hours after the last administration, animals were weighed and autopsied. Seminal vesicles, epididymis, prostate and elevator anis and bulbo-carvenous (LABC) were dissected, separated from adherent tissues and weighed.

\section{Uterotrophic bioassay}

Estrogenic and antiestrogenic activities of hydro-alcoholic leaf extract of $P$. butyracea were assessed using uterotrophic bioassay (Odum et $a l ., 1997$; Andrade et $a l ., 2002$; OECD, 2007). Immature female Wistar rats aged 21 to 23 days weighing $35,85 \pm 4,14 \mathrm{~g}$, were randomly divided into 6 groups of 6 rats each and treated daily for three consecutive days. For assessment of estrogenic activity, groups 1 and 2 were given 100 and $200 \mathrm{mg} / \mathrm{kg}$ bw of hydroalcoholic leaf extract of $P$. butyracea. Groups 3 and 4 were treated with sterilized water and $10 \mu \mathrm{g} / \mathrm{kg}$ bw of $17 \beta$ estradiol 3-benzoate (E2-B) and were considered as blank and reference control, respectively. For antiestrogenic activity, group 5 was co-treated with E2-B $(10 \mu \mathrm{g} / \mathrm{kg})$ and $100 \mathrm{mg} / \mathrm{kg}$ of the extract whereas group 6 was co-treated with E2-B $(10 \mu \mathrm{g} / \mathrm{kg})$ and $200 \mathrm{mg} / \mathrm{kg}$. Reference control was administered intraperitoneally whereas the sterilized water and extract were given by gavage. All the treatments were done for three consecutive days. Twenty-four (24) hours after the last treatment, animals were autopsied. Ovaries, uteri and adrenals were dissected, separated from adherent tissues and weighed. 


\section{Statistical analysis}

Data are presented as mean \pm standard error of mean (S.E.M.) and analyzed using Graph Pad Prism version 5.03. One-way analysis of variance (ANOVA) followed by Dunnett's comparison test were used to assess differences between groups. A value of $\mathrm{p}<0.05$ was considered as statistically significant. Excel 2016 was used to build graphs.

\section{Results:-}

\section{Yeast estrogen/androgen screens (YES/YAS)}

The ability of hydro-alcoholic leaf extract of $P$. butyracea to interact with human estrogen or androgen receptors was assessed using yeast estrogen/androgen screen (YES/YAS). The sensibility and the specificity of yeast recombinant screens were assessed using $17 \beta$-estradiol and dihydrotestosterone as positive controls in YES and YAS, respectively. Both $17 \beta$-estradiol and dihydrotestosterone induced deep changes of colour in dose-dependent manner, therefore, dose-response curves were achieved using these positive controls (data not show). However, hydro-alcoholic leaf extract of $P$. butyracea did not induce a change of colour irrespective of the dose range $(0.1$ $\mu \mathrm{g} / \mathrm{mL}-100 \mu \mathrm{g} / \mathrm{mL}$ ) (data not show). Treatment did not affect growth and density of yeasts, as turbidity was approximatively the same in either controls (17ß-estradiol, dihydrotestosterone and DMSO $1 \%$ ) or in the treatment groups (data not show).

Antiestrogenic and antiandrogenic activity of hydro-alcoholic extract was also screened. The hydro-alcoholic extract induced inhibition of estrogenic or androgenic activities in dose-dependent manner (Figure 1).

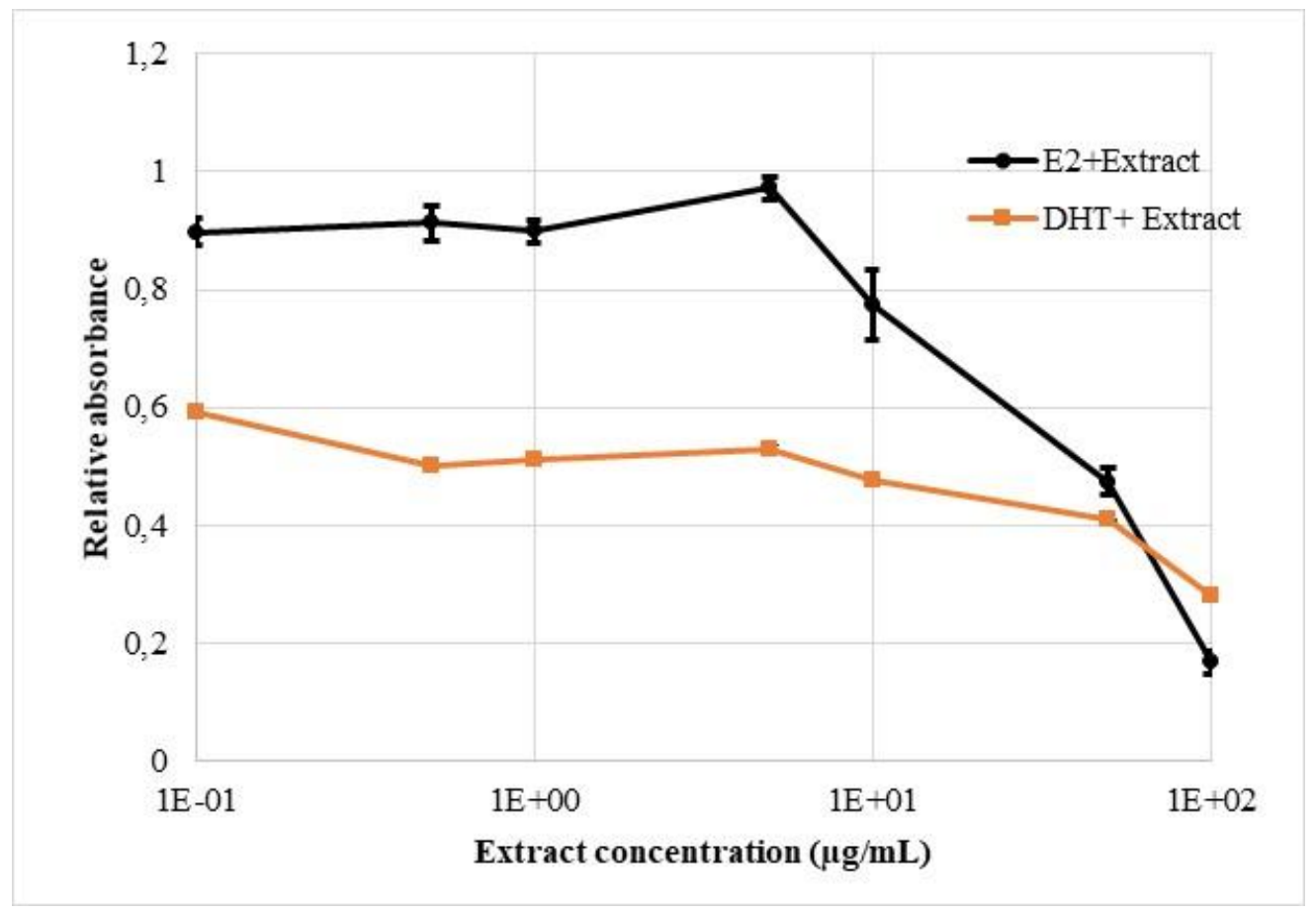

Figure 1: Anti-estrogenic and anti-androgenic dose-response curves of hydro-alcoholic leaf extract of $P$. butyracea in hER screen and hAR screen, respectively. In hER screen, treatment was performed with $10^{-1}$ to $10^{2} \mu \mathrm{g} / \mathrm{ml}$ $P$. butyracea leaf extract in the presence of $5 \times 10^{-7} \mathrm{M} \mathrm{E2}$. Similarly, in hAR screen treatment was performed with $10^{-}$ ${ }^{1}$ to $10^{2} \mu \mathrm{g} / \mathrm{ml}$ P. butyracea leaf extract in the presence of $5 \times 10^{-7} \mathrm{M}$ DHT.

\section{Uterotrophic bioassay}

\section{Animal body weight and relative organs weight}

Uterotrophic bioassay was performed to assess possible estrogenic and antiestrogenic activities of hydro-alcoholic leaf extract of $P$. butyracea. The uterine relative weight of rats treated with reference control (E2-B) increased significantly $(\mathrm{p}<0.05)$ compared to blank control (Figure $2 \mathrm{a})$. In the co-treatment groups with 17ß-estradiol 3benzoate and the extract a significantly $(\mathrm{p}<0.001)$ increased relative uterine weight compared to blank control was also recorded. The co-treatment with the extract and E2-B potentiated slightly $(\mathrm{p}>0.05)$ the increase of the uterine 
relative weight compared to E2-B-treated rats. In other words, as no-significant variations of uterine relative weights relative to reference control could be resolved, no evidence for anti-estrogenicity in vivo could be obtained.

The ovarian relative weight of rats treated with the hydro-alcoholic extract of $P$. butyracea did not change significantly ( $p>0.05$ ) compared to blank control. Similarly, the reference control (E2-B) did not induce significant variation of the ovarian weight compared to blank control however the ovarian relative weight of the rats cotreated with the dose $200 \mathrm{mg} / \mathrm{kg}$ and the reference control increase significantly compared to blank control (Figure $2 \mathrm{~b}$ ).

The group treated with the E2-B and the group co-treated with E2-B and the extract showed a non-significant increase of adrenals relative weight compared to blank control. (data not show).

\section{Uterus}

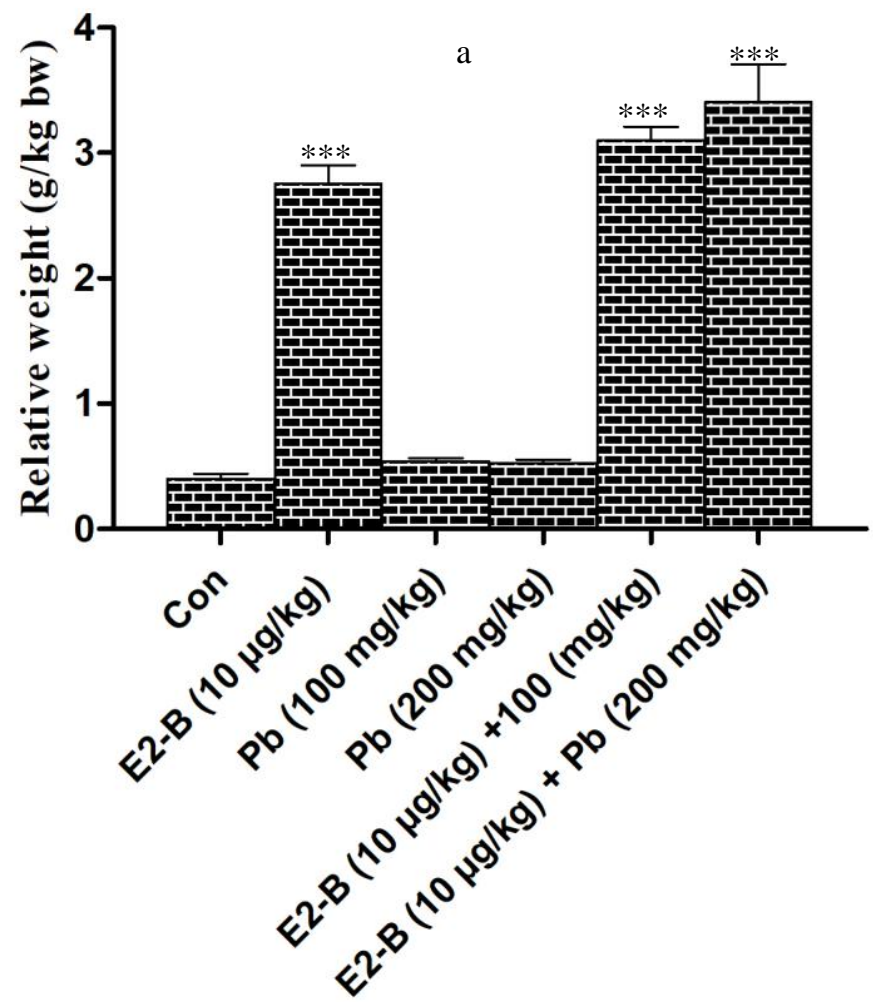

Treatments 


\section{Ovaries}

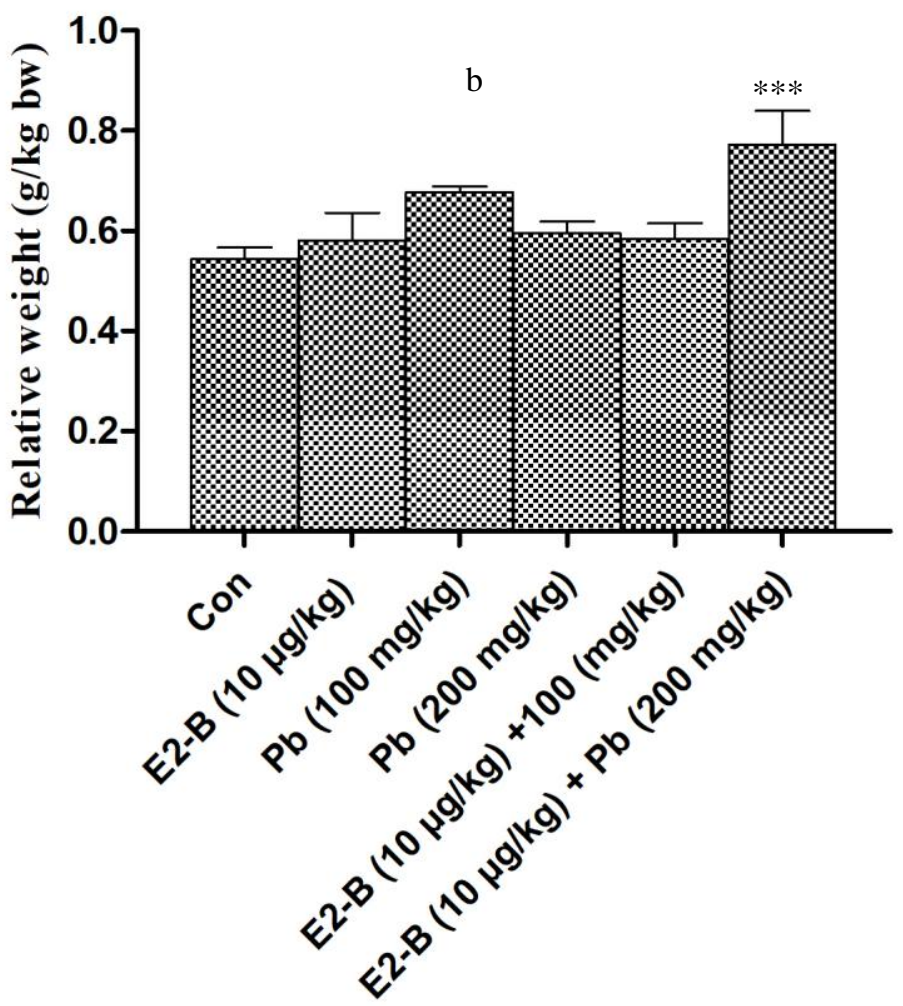

\section{Treatments}

Figure 2:-Relative uterine wet weight (a) and relative weight of ovaries after three consecutive days of treatment with hydro-alcoholic leaf extract of $P$. butyracea. *** denotes statistical significance compared to blanc control (p < 0.001). Con: blank control, E2-B: $17 \beta$-estradiol 3-benzoate, Pb: Pentadesma butyracea (100 and $200 \mathrm{mg} / \mathrm{kg}$ bw).

\section{Hershberger bioassay}

Animal body weight and relative organ body weight

After 10 consecutive days of treatment, reference control and hydro-alcoholic leaf extract of $P$. butyracea (100 and $200 \mathrm{mg} / \mathrm{kg}$ ) did not affect the body weight gain of immature male Wistar rats. The body weight gain was comparable among all treatment groups. Similarly, the co-treatment with extract and TP did not impact on body weight gain of the immature rats (data not show).

The Hershberger bioassay was performed to assess possible androgenic and antiandrogenic properties of the hydroalcoholic leaf extract of $P$. butyracea.

The relative weight of weight of prostate of rats treated with reference control (TP) increased significantly (p < 0.001) in comparison to the blank control. The leaf extract at the dose of 100 and $200 \mathrm{mg} / \mathrm{kg}$ bw induced a slight increase $(\mathrm{p}>0.05)$ of relative weight of the prostate compared to blanc control. Although non-significative ( $\mathrm{p}>$ 0.05), the dose of $100 \mathrm{mg} / \mathrm{kg}$ bw induced more pronounced effect than the dose of $200 \mathrm{mg} / \mathrm{kg}$ bw. Compared to reference control (TP), the cotreatment of the leaf extract and TP induced non-significant $(\mathrm{p}>0.05)$ decrease of relative weight of prostate (Figure 3 ). 


\section{Prostate}

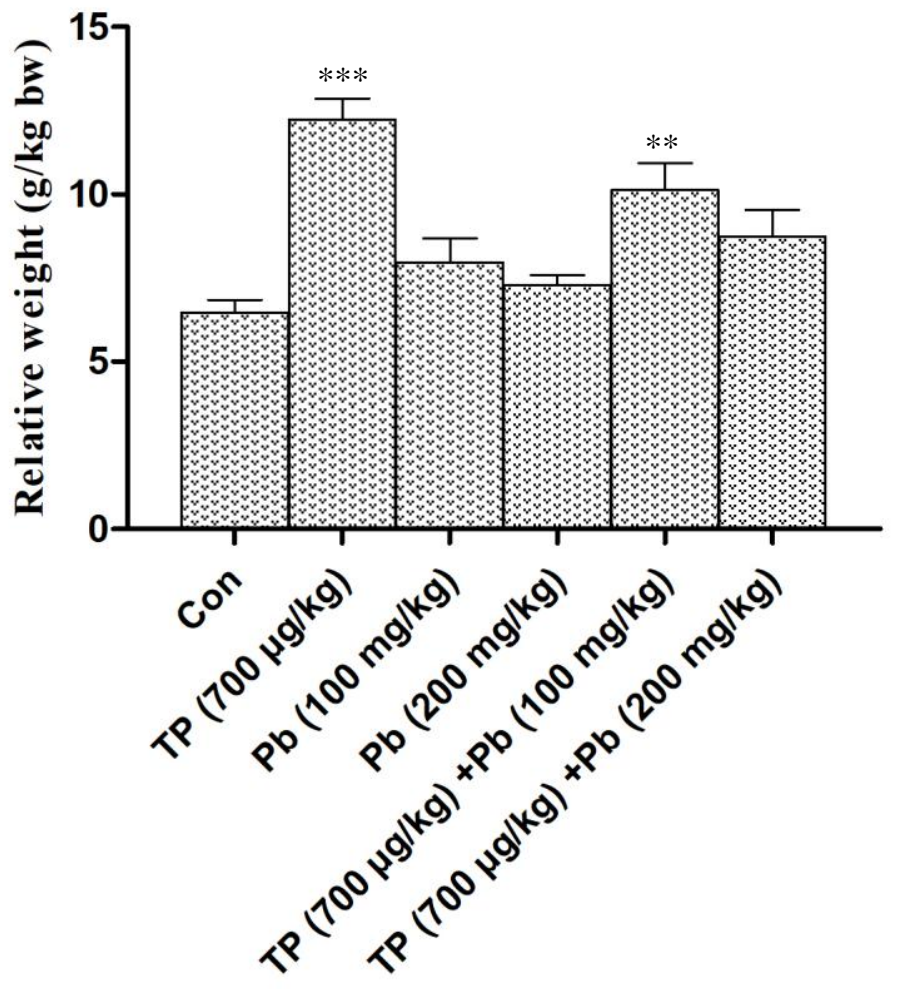

\section{Treatments}

Figure 3: Immature male Wistar rats' prostate relative weight after ten consecutive days of treatment with hydroalcoholic extract of $P$. butyracea leaf. ***denotes statistically significant compared to control ( $\mathrm{p}<0.001)$, Con: blank control, TP: Testosterone propionate, Pb: Pentadesma butyracea (100 and $200 \mathrm{mg} / \mathrm{kg}$ bw).

The relative weight of epididymis of rats treated with reference control (TP) increased significantly $(\mathrm{p}<0.05)$ in comparison to the blank control (Figure 4). The leaf extract induced non-significant $(p>0.05)$ decrease of relative weight of epididymis in comparison to the blanc control. The relative weight of the epididymis of rats co-treated with the leaf extract at the dose of $200 \mathrm{mg} / \mathrm{kg}$ bw and TP increased significantly ( $\mathrm{p}<0.05$ ) compared to blank control. The cotreatment of the rats with the leaf extract $(200 \mathrm{mg} / \mathrm{kg}$ bw) and TP induced significant $(\mathrm{p}<0.001)$ increase of relative weight of the epididymis in comparison to blank control. 


\section{Epididymis}

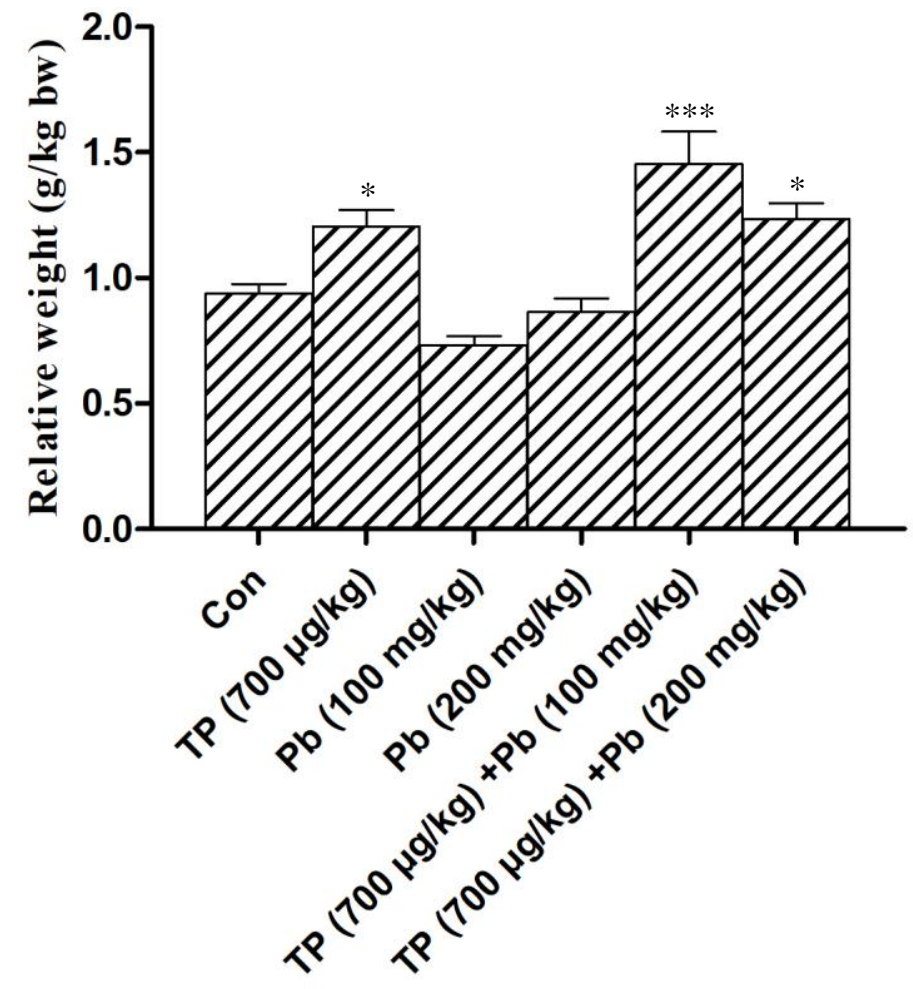

Treatments

Figure 4: Immature male Wistar rats' epididymis relative weight after ten consecutive days of treatment with hydroalcoholic extract of $P$. butyracea leaf. ***denotes statistically significant compared to control ( $<<0.001)$, Con:

blank control, TP: Testosterone propionate, $\mathrm{Pb}$ : Pentadesma butyracea (100 and $200 \mathrm{mg} / \mathrm{kg} \mathrm{bw}$ ).

Seminal vesicles relative weight of rats treated with reference control (TP) increased significantly $(p<0.001)$ in comparison to the blank control. Though not statistically significant, the seminal vesicle relative wet weight was found to be increased in response to the $P$. butyracea extract, being 1.9-fold as high among the animals treated with the higher dose compared to the blank control group (100 mg/kg vs. $200 \mathrm{mg} / \mathrm{kg}$ bw; Figure 5). Compared to reference control (TP), the cotreatment of the rats with leaf extract at the dose of $200 \mathrm{mg} / \mathrm{kg}$ and TP induced significant $(\mathrm{p}<0.05)$ decrease of seminal vesicles relative weight. 


\section{Seminal vesicles}

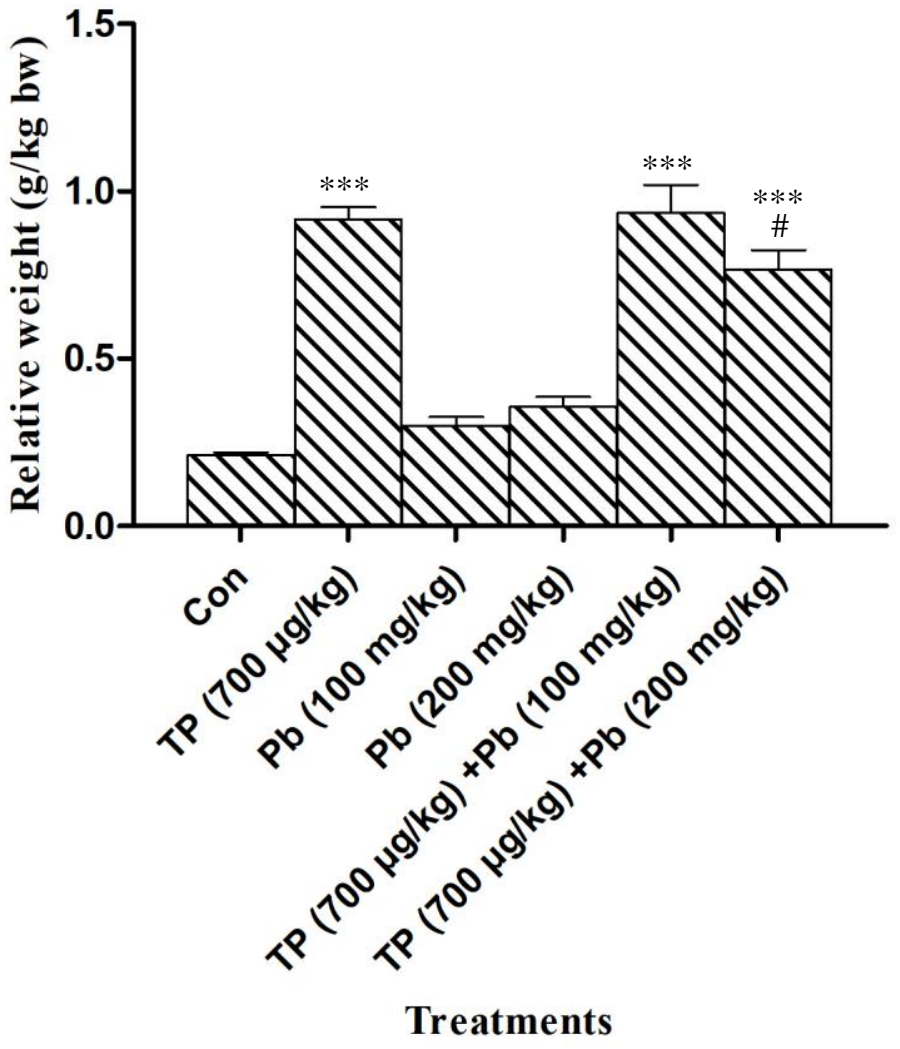

Figure 5: Immature male Wistar rats' seminal vesicles relative weight after ten consecutive days of treatment with hydro-alcoholic leaf extract of $P$. butyracea. ***denotes statistically significant compared to blank control (p < 0.005), \# denotes statistically significant compared to reference control (TP_700 $\mu \mathrm{g} / \mathrm{kg})(\mathrm{p}<0.05)$. Con: blank control, TP: Testosterone propionate, Pb: Pentadesma butyracea (100 and $200 \mathrm{mg} / \mathrm{kg}$ bw).

No significant change was recorded between treated and controls groups on testicles relative weights however a slight decrease $(\mathrm{p}>0.05)$ was recorded on the reference control relative weight (data not show).

Reference control induced non-significant $(\mathrm{p}>0.05)$ increase of the relative weight of EABC. Similarly, the cotreatment with leaf extract at the dose of $100 \mathrm{mg} / \mathrm{kg}$ bw and TP induced slight increase of relative body weight of EABC in comparison to blank control. In comparison to reference control, the cotreatment with the dose $100 \mathrm{mg} / \mathrm{kg}$ bw of leaf extract reversed the effect of TP on EABC. The dose $100 \mathrm{mg} / \mathrm{kg}$ induced significantly increased $(\mathrm{p}<$ 0.01) of EABC relative weight compared to blank control. The dose of $200 \mathrm{mg} / \mathrm{kg}$ inhibited significantly the increase of EABC relative weight of testosterone propionate-treated rats (Figure 6). 


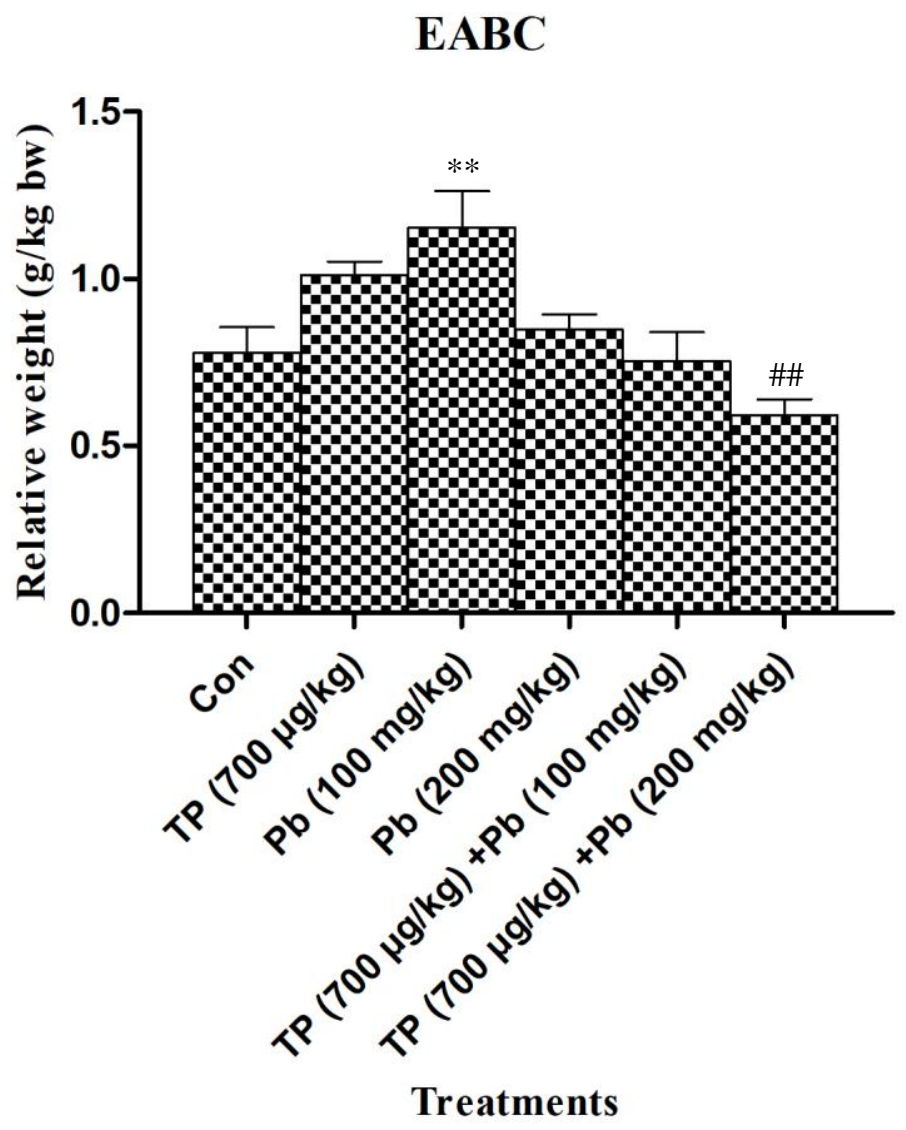

Figure 6:-Immature male Wistar rats' LABC relative weight after ten consecutive days of treatment with hydro-alcoholic leaf extract of $P$. butyracea. \#\# denotes statistically significant compared to reference control (TP_700 $\mu \mathrm{g} / \mathrm{kg}$ ) ( $<<0.01), * *$ denotes statistically significant compared to control ( $\mathrm{p}<0.01)$, Con: blank control, TP: testosterone propionate, Pb: Pentadesma butyracea (100 and $200 \mathrm{mg} / \mathrm{kg}$ ).

Reference control induced significant $(\mathrm{p}<0.05)$ increase of adrenals relative weight compared to blank control. Similarly, the co-treatment with the extract at the dose of $100 \mathrm{mg} / \mathrm{kg}$ and $\mathrm{TP}$ did not attenuate this effect and elevation of adrenals relative weight compared to blank control persisted. All the other treatments were without significant impact $(\mathrm{p}>0.05)$ on the relative weight of adrenals when compared to the blank control. Nevertheless, the cotreatment of the extract at the dose $200 \mathrm{mg} / \mathrm{kg}$ bw and TP reversed the effect of TP on adrenals (data not show).

\section{Discussion:-}

The research on medicinal plants which can be used for management of menopausal symptoms and prevention or treatment of hormone-related diseases such as breast and prostate cancer has become a promising endeavour for scientists. Thus, there are many in vitro and in vivo studies investigating hormonal activities of traditionally used medicinal plants (Cordial et al., 2006; Parhizkar et al., 2011; Basu et al., 2016).

P. butyracea is used traditionally for the treatment of breast pain and several reproductive disorders (AvocevouAyisso et al., 2011; Natta et al., 2011). It is well known that many reproductive disorders are hormone-related. Thus, phytoestrogen and phytoandrogenic activity of $P$. butyracea was assessed by in vivo and in vitro assays. In immature uterotrophic bioassay, hydro-alcoholic leaf extract of $P$. butyracea did not cause increase of the relative uterine wet weight unlike in E2-B-treated rats. Moreover, the extract was unable to prevent the E2-B-induced increase of the uterine relative weight. According to Odums et al. (1997), Kang et al. (2000) and OECD (2007) the immature uterotrophic bioassay is the recommended procedure for the detection of estrogenic and antiestrogenic activities. Indeed, in response to the estrogenic treatment there is a marked increase of uterine wet weight of immature female 
rats. Mechanistically, this increase of uterine weight is due to a mitogenic activity of uterine cells and of fluids retention in these cells (Owens and Ashby, 2002). In the present study, the P. butyracea extract failed to cause an increase of the uterus weight, hence the extract did not exhibit estrogenic properties at the tested doses (100 and 200 $\mathrm{mg} / \mathrm{kg}$ ). On the other hand, Routledge and Sumpter (1996) and Sohoni and Sumpter (1998) suggested the yeast estrogen screen for detection of estrogenic/antiestrogenic compounds. In this assay, we confirm that the extract does not exhibit estrogenic activity. However, the extract showed antiestrogenic activity in the yeast estrogen screen in vitro, which was not detectable in vivo. This might be due to metabolism and other unknown factors involved and may explain the difference of finding between in vivo and in vitro results.

Yeast androgen screen revealed that the hydro-alcoholic leaf extract had antiandrogenic activity. The OECD 441 guideline recommends immature Hershberger bioassay to screen androgenic/antiandrogenic activities in vivo (OECD, 2009). In Hershberger bioassay with immature rodents, androgenic compounds induce the increase of accessory sex glands including prostate, seminal vesicles, epididymis aa well as other organs such as the muscles elevator anis and bulbocavernosus (OECD, 2009; Yamasaki et al., 2004). According to OECD (2009), there are needs of the response of at least two accessory sex glands to evoke androgenic activity. subsequently, this bioassay confirmed that the extract did not present androgenic activity because it failed to increase the wet weight of accessory sex glands excepted elevator anis and bulbo-carvenous, but reversed androgenic activity induced by testosterone treatment of immature rats. As the extract induced increase of elevator anis and bulbo-carvenous relative weight and inhibited the effect of testosterone in other sex glands that it may act as Selective Androgen Receptor Modulator (SARM). These findings are consistent with our previous study (Tindano et al., 2017) which showed that a $P$. butyracea seed extract also exhibits antiandrogenic activity in vivo. Beside this it confirmed the results from the yeast androgen screen. Zierau et al. (2003) reasoned that antiandrogens from plant material may be useful for treatment of hormone related diseases. Thus, antiandrogenic compounds may inhibit prostate cancer progression by blocking androgen-dependent gene transcription. According to Koyama (2011), plant extracts could block androgenic activity on target cells through two main mechanisms. The first mechanism is the inhibition of the binding of an androgen to the androgen receptor. Secondly, the extract could inhibit $5 \alpha$-reductase activities and, subsequently, block the conversion of testosterone to dihydrotestosterone (Fugita et al., 2005). Lund et al. (2004) suggest that plant-derived antiandrogens, namely equol can directly bind to the androgen such as dihydrotestosterone and markedly reduce the level of free androgens available for target cells. Other studies have been published on beneficial effects of botanical antiandrogens for prevention or treatment of prostate cancer (Scheich et al., 2006; Bobach et al., 2014). Moreover, antiandrogenic compounds may down-regulate target cell proliferation by an increase of sex hormone binding globulin (SHBG) and, consequently a decrease of free, bioavailable endogenous androgens (Kolukula and Anderson, 2011). Finally, antiandrogens could also downregulate the androgen receptor by decreasing the Heat-shock protein (Hsp 90) chaperone activity, a protein required for steroid hormone receptors stabilization (Basack et al., 2008; Li and Buchener, 2013).

Overall, previous studies showed that $P$. butyracea contains polyphenols including coumarins, terpenoids, flavonoids, steroids, anthocyans (Hilou et al., 2017; Tindano et al., 2017). Some of these polyphenols show structural similarity to estrogens or androgens and might bind to estrogen or androgen receptors of mammalians and subsequently influence endogenous hormone activities. Therefore, antiestrogenic and antiandrogenic activities found in our study may be due to these polyphenols of $P$. butyracea. Indeed, we showed recently that leaf extract of P. butyracea contains tannins, steroids and triterpens, flavonoids, antraquinones, anthocyanosids and saponosids (Tindano et al, 2018) Some of these polyphenols are well-known as phytoestrogens or phytoandrogens. Recently, the role of phytestrogens and phytoandrogens is subject of great discussion (Lecomte et al., 2017). Moreover, phytoestrogens and phytoandrogens could exert antagonistic effects on sex hormone receptors and, thereby, potentially block the proliferation of hormone-dependent cancer cells (Basack et al., 2008).

\section{Conclusion:-}

The hydro-alcoholic leaf extract of P. butyracea exhibited antiandrogenic and antiestrogenic activity. However, the extract did not have estrogenic activity. Similarly, the showed androgenic activity on accessory sex organs excepted elevator anis and bulbo-carvenous. The extract could have beneficial effects as Selective Androgen Receptor Modulators. Nevertheless, further studies are needed to explain the mechanism of action of the extract and reveal the bioactive compounds in the extract. Therefore, it will be necessary to test the hydro-alcoholic extract and fractions of it on breast and prostate cancers lines. 


\section{Acknowledgements:-}

This work was supported in part by the International Atomic of Energy Agency (IAEA, BKF-5011) and Technical University of Dresden as well as by the help and support of Susanne Broschk and Antje Beyer. We would like to thank them sincerely.

\section{References:-}

1. Avocevou-Ayisso, C., Avohou, T. H., Oumorou, M., Dossou, G., Sinsin B. (2011): Ethnobotany of Pentadesma butyracea in Benin: A quantitative approach. Ethnobotany Research \& Applications, 9: 151-166.

2. Andrade, A. J. M., Araujo, S., Santana, G. M., Ohi, M., Dalsenter, P. R. (2002): Screening for in vivo (anti)estrogenic and (anti)androgenic activities of technical and formulated Delmethrin. Regul. Toxicol. Pharmacol., 35: 379-382. doi:10.1006/rtph.2002.1554.

3. Basack, S., Pookot, D., Noonan, E. J., Dahiya, R. (2008): Genistein down-regulates androgen receptor by modulating HDAC6-Hsp90 chaperone function. Mol Cancer Ther, 7 (10): 3195-3202.

4. Basu, P., Sunny, S., Maier, C. (2016): Estrogenic and antiestrogenic activities of commercial dietary supplements containing herbal ingredients and isoflavones. Int. J. Pharm. Pharmaceu. Sci., 8 (3): 307-312.

5. Bobach, C., Schurwanz, J., Franke, K., Denkert, A., Sung, T. V., Kuster, R., Mutiso, P. C., Seliger, B., Wessjohann, L. A. (2014): Multiple readout assay for hormonal (androgenic and antiandrogenic) and cytotoxic activity of plant and fungal extracts based on differential prostate cancer cell line behaviour. J. Ethnopharmacol., 155: 721-730.

6. Chen, G., Wilczek, B., Warner, M., Gustafsson, J.-A., Landgren, B.-M. (2007): Isoflavone treatment for acute menopausal symptoms. J. Nor. Amer. Menop. Soc., 14 (3): 468-473. doi: 10.1097/GME.0b013e31802cc7d0.

7. Cordial, R. R., Baxa-Daguplo, B. M., Fermanes, P. M. S., Garcia, A. S., Clavel, R. M. M., Ombac-Herradura, M., Javier, J. C., Santos, R. R. (2006): Estrogenic Activity of Pueraria phaseoloides Roxb. Benth Evaluated in Ovariectomized Rats. Philippine J. Sci., 135 (1): 39-48.

8. Delma,_S. (2011) : Apport de la chimiothérapie dans la prise en charge des cancers du sein dans trois structures sanitaires publiques de la ville de Ouagadougou, Burkina Faso à propos de 65 cas. Doct. Med. Univ. Ouaga., 91p.

9. Fugita, R., Lui, L., Shimizu, K., Konishi, F., Noda, K., Kumamoto, S., Ueda, C., Tajiri, H., Kaneko, S., Suimi, Y., Kondo, R. (2005): Anti-androgenic activities of Ganoderma lucidium. J. Ethnopharmacol., 102:107-112.

10. Hilou, A., Bougma, A., Dicko, H. (2017): Phytochemistry and Agro-Industrial Potential of Native Oilseeds from West Africa: African Grape (Lannea microcarpa), Marula (Sclerocarya birrea), and Butter Tree (Pentadesma butyracea). Agricult. 7 (24): 1-11. doi:10.3390/agriculture7030024.

11. Kaboré, F. A., Zango, B., Kambou, T., Ouedraogo, A. S., Bambara, A., Yameaogo, C., Kirokoya, B., Lompo, O. (2014): Prostate cancer diseases characteristics at the time of diagnosis and initial treatment offered in tertiary hospital at Ouagadougou (Burkina Faso). Open J uro., 4: 7-12. http://dx.doi.org/10.4236/oju.2014.41002

12. Kang, K. S., Kim, H. S., Ryu, D. Y., Che, J. H., Lee, K. S. (2000): Immature uterotrophic assay is more sensitive than ovariectomized uterotrophic assay for the detection of estrogenicity of p-nonyphenol in Sprague-Dawley rats. Toxicol. Letters, 118: 109-115.

13. Koyama, T. (2011): New botanical materials with anti-androgenic activity. Prostate Cancer - Original Scientific Reports and Case Studies, Dr. Philippe E. Spiess (Ed.), ISBN: 978-953-307-342-2, InTech, Available from: http://www.intechopen.com/books/prostate-cancer-original-scientific-reports-and-case-studies/new-botanicalmaterials-with-anti-androgenic-activity.

14. Kolukula, S., Anderson, R. J. (2011): Phytoestrogens and their potential roles in prostate cancer prevention and treatment. J. Canc. Sci. Ther. S1, doi: 10.4172/1948-5956.S1-002.

15. Lecomte, S., Demay, F., Ferrière, F., Pakdel, F. (2017) : Phytochemicals targeting estrogen receptors: beneficial rather than adverse effects? I. J. of Mol. Sci., 18: 1-19. doi:10.3390/ijms18071381.

16. Levitsky, D. O., Dembitsky, V. M. (2015): Anti-breast Cancer Agents Derived from Plants. Nat. Prod. Bioprospect., 5:1-16.

17. Li, J., Buchner, J., (2013):_The Hsp90 molecular chaperone machinery. Biomed. J., 36(3): 106-117.

18. Lund, T. D., Munson, D. J., Haldy, M. E., Setchell, K. D. R., Lephart, E. D., Handa, R. J. (2004): Equol is a novel anti-androgen that inhibits prostate growth and hormone feedback. Biol. Reprod., 70: 1188-1195.

19. Macgregor, J. I., Jordan, V. C. (1998): Basic guide to the mechanism of antiestrogen action. Pharmacol. Reviews, 52 (2): 151-196.

20. Natta, A., Sogbégnon, R., Tchobo, F. (2011) : Connaissances endogènes et importances du Pentadesma butyracea (Clusiaceae) pour les populations autochtones au nord-ouest Benin. Fruit, vegetable and cereal sci. biotechnol., 4(1): 18-25.

21. Noudogbessi, J. P., Delort, L., Chalard, P., Billard, H., Figuerodo, G., Ruiz, N., Chalchat, J. C., Sohounhloue, D., Chezet, F. C. (2013): Anti-proliferative activity of four aromatic plants of Benin. J. Nat. Product, 6: 123-131. 
22. Odum, J., Lefevre, P. A., Tittensor, S., Paton, D., Routledge, E. J., Beresford, N. A., Sumpter, J. P., Ashby, J. (1997): Rodent uterotrophic Assay: critical Protocol features, studies with Nonyl phenols, and comparison with yeast estrogenicity assay. Regulat. Toxicol. Pharmacol., 25: 176-188.

23. OECD (2007): Guidelines for the testing of chemicals. Uterotrophic bioassay in rodents: a short-term screening test for estrogenic properties. 440: 1-21.

24. OECD (2009): OECD guideline for testing of chemicals. Hershberger bioassay in rats: a short-term screening assay for (anti) androgenic properties. 441:1-20.

25. Ouedraogo, A., Lykke, A. M., Lankoandé, B., Korbéogo G. (2013): Potentials for promoting oil products identified from traditional knowledge of native trees of Burkina Faso. Ethnob. Res. Appl., 11: 071-083.

26. OMS (2013) : Dernières statistiques mondiales sur le cancer. En augmentation à 14,1 millions de nouveau en 2012 : l'augmentation marquée du cancer du sein demande une réponse. Communiqué de presse 223. Centre Internationale de Recherche sur le cancer, $2 \mathrm{p}$.

27. Owens, J. W., Ashby, J. (2002): Critical review and evaluation of uterotrophic bioassay for identification of possible estrogen agonist and antagonists: In support of the validation of uterotrophic protocols for the laboratory rodent. Critical Reviews Toxicol., 32 (6): 445-520.

28. Parhizkar, S., Latif, L. A., Rahman, S. A., Dollah, M. A., Parichehr, H. (2011): Assessing estrogenic activity of Nigella sativa in ovariectomized rats using vaginal cornification assay. Afr. J. Parma. Pharmacol., 5 (2): $137-142$.

29. Routledge, E. J., Sumpter, J. P. (1996): Estrogenic activity of surfactants and some of their degradation products assessed using recombinant yeast screen. Environm. Toxicol. Chem., 15(3):241-248.

30. Routledge, E. J., Sumpter, J. P. (1997): Structural features of alkylphenolic chemicals associated with estrogenic activity. The J. Biol. Chem., 272 (6): 3280-3288.

31. Rietjens, I. M. C. M., Louise, J., Beekman, K. (2017) : The potential health effects of dietary phytoestrogens. British J. Pharmacol., 174: 1263-1280.

32. Schleich, S., Papaioannou, M., Matusch, R. (2006): Extract from Pygeum africanum and other botanical species with antiandrogenic activity, Planta Med., 72: 807-813.

33. Siegel, R. L., Miller, K. D., Jemal A. (2017): Cancer statistics, 2017. Ca Cancer J. Clin., 67: 7-30.

34. Sinsin, B., Sinadouwirou, A.T. (2003): Valorisation socio-économique et pérennité du Pentadesma butyracea Sabine en galeries forestières du Bénin. Cahiers Agricult., 12 (2) : 75-79.

35. Sohoni P., Sumpter J. P. (1998): Several environmental oestrogens are also anti-androgens. J. Endocrinol., 158: 327339.

36. Tala, M. F., Wabo, H. K., Zeng, G. Z., Ji, C. J., Tane, P., Tan, N. H. (2013): A prenylated xanthone and antiproliferative compounds from leaves of Pentadesma butyracea. Phytochem. Letters, 6: 326-330.

37. Tamokou, J. D., Chouna, J. R., Fischer-Fodor, E., Chereches, G., Barbos, O., Damien, G., Benedec, D., Duma, M., Efouet, A. P. N., Wabo, H. K., Kuate, J. R., Mot A., Silaghi-Dumitrescu, R. (2013): Anticancer and antimicrobial activities of some antioxidant-rich Cameroonian medicinal plants. Plos One, 8 (2): 1-14. www.plosone.org

38. Tindano, B., Bayala, B., Doukouré, M., Belemtougri, G. R., Tamboura, H.H., Sawadogo, L. (2017): Phytochemical composition, acute toxicity and biological activity of hydroalcoholic extract of Pentadesma butyracea (Clusiaceae Sabine (1824)) seeds. J. Med. Plants Res., 11 (42): 656-664.

39. Tindano, B., Bayala, B., Guenné, S., Doukouré, M., Kiendrebéogo, M., Belemtougri ,G. R., 2018. Innocuity et antioxidant activities of Pentadesma butyracea (1824) leaves for its use in hormone replacement therapy. Cameroon J. Experm. Biol., 12(1): 32-40.

40. Yamasaki, K., Sawaki, M., Noda, S., Muroi, T., Takakura, S., Mitoma, H., Sakamoto, S., Nakai, M., Yakabe, Y. (2004): Comparison of the Hershberger assay and androgen receptor binding assay of twelve chemicals binding assay of twelve chemicals. Toxicol., 195: 177-186.

41. Zierau, O., Morrissey, C., Waston, R. W. G., Schwab, P., Kolba, S., Metz, P., Vollmer, G. (2003): Antiandrogen activity of the phytoestrogen Naringenin, 6-1,1-Dimethylallyl)naringenin and 8-prephenylnaringenin. Planta Med., 69: $856-858$

42. Zierau, O., Geis, R.-B., Schwab, P., Metz, P., Vollmer, G. (2004): Uterine effect of phytoestrogen 6-(1,1Dimethylallyl)naringenin in rats. Planta Med., 70: 590-593. DOI 10.1055/s-2004-827178.

43. Zimmermann, M. (1983): Ethical guidelines for investigations of experimental pain in conscious animals. Pain.16: 109-110. 